\title{
Transport of ixodid ticks and tick-borne pathogens by migratory birds
}

\author{
Gunnar Hasle * \\ Department of Biology, University of Oslo, Blindern, Norway
}

\section{Edited by:}

Agustín Estrada-Peña, University of

Zaragoza, Spain

Reviewed by:

Philip Stewart, Rocky Mountain

Laboratories/NIAID/NIH, USA

Agustín Estrada-Peña, University of

Zaragoza, Spain

*Correspondence:

Gunnar Hasle, Reiseklinikken - Oslo

Travel Clinic, St. Olavs plass 3,

N-0165 Oslo, Norway

e-mail: hasle@reiseklinikken.com
Birds, particularly passerines, can be parasitized by Ixodid ticks, which may be infected with tick-borne pathogens, like Borrelia spp., Babesia spp., Anaplasma, Rickettsia/Coxiella, and tick-borne encephalitis virus. The prevalence of ticks on birds varies over years, season, locality and different bird species. The prevalence of ticks on different species depends mainly on the degree of feeding on the ground. In Europe, the Turdus spp., especially the blackbird, Turdus merula, appears to be most important for harboring ticks. Birds can easily cross barriers, like fences, mountains, glaciers, desserts and oceans, which would stop mammals, and they can move much faster than the wingless hosts. Birds can potentially transport tick-borne pathogens by transporting infected ticks, by being infected with tick-borne pathogens and transmit the pathogens to the ticks, and possibly act as hosts for transfer of pathogens between ticks through co-feeding. Knowledge of the bird migration routes and of the spatial distribution of tick species and tick-borne pathogens is crucial for understanding the possible impact of birds as spreaders of ticks and tick-borne pathogens. Successful colonization of new tick species or introduction of new tick-borne pathogens will depend on suitable climate, vegetation and hosts. Although it has never been demonstrated that a new tick species, or a new tick pathogen, actually has been established in a new locality after being seeded there by birds, evidence strongly suggests that this could occur.

Keywords: ticks, migratory birds, tick-borne pathogens, tick-borne encephalitis virus, borrelia, babesia

\section{INTRODUCTION}

There is ample evidence that birds, particularly passerines, can be parasitized by Ixodid ticks (Hoogstraal et al., 1961, 1963; Nuorteva and Hoogstraal, 1963; Anderson and Magnarelli, 1984; Mehl et al., 1984; Weisbrod and Johnson, 1989; Stafford et al., 1995; Olsen et al., 1995a; Nicholls and Callister, 1996; Smith et al., 1996; Ishiguro et al., 2000; Alekseev et al., 2001; Bjöersdorff et al., 2001; Scharf, 2004; Comstedt et al., 2006; Poupon et al., 2006; Ogden et al., 2008; Hasle et al., 2009). These ticks may be infected with tick-borne pathogens, like Borrelia spp. (Olsen et al., 1995a,b; Gylfe et al., 2000; Hanincova et al., 2003; Comstedt et al., 2006; Poupon et al., 2006; Ogden et al., 2008; Hasle et al., 2010; Kjelland et al., 2010; Franke et al., 2012; Socolovschi et al., 2012), Anaplasma spp. (Alekseev et al., 2001; Bjöersdorff et al., 2001; Daniels et al., 2002; Ogden et al., 2008; Franke et al., 2012), Babesia spp. (Hasle et al., 2011), Rickettsia/Coxiella (Elfving et al., 2010; Socolovschi et al., 2012) and Tick-borne encephalitis virus (TBEV) (Waldenström et al., 2007; Geller et al., 2013). The prevalence of ticks on birds varies between years, season, locality and different bird species. The prevalence of ticks on different species depends mainly on the degree of feeding on the ground (Mehl et al., 1984; Hasle et al., 2009; Marsot et al., 2012). In particular, thrushes, i.e., the Turdus spp. in Europe (Hasle et al., 2009), Russia (Alekseev et al., 2001) and Japan (Ishiguro et al., 2000), and Catharus spp. in North America (Smith et al., 1996), have a high prevalence of tick infestation. e.g., in our Norwegian material
$31.5 \%$ of blackbirds, Turdus merula, and $25.1 \%$ of song thrushes, T. philomelos, were infested by ticks (Hasle et al., 2009). Blackbirds are often infected with several ticks on each bird. Five per cent of blackbirds $(N=543)$ had ten or more ticks, and one single blackbird had 66 nymphs of Ixodes ricinus (own data). Only one study has compared historic and new data concerning ticks on birds. Hasle et al. (2009) compared data from 2003 to 2005 with Mehl et al.'s (1984) data from 1965 to 1970 on two Norwegian bird observatories, and found an increase of the prevalence of tick infestation on passerine northward migrating birds from 4.2 to $6.9 \%(p<0.001)$. Birds can easily cross barriers, like fences, mountains, glaciers, desserts and oceans, which would stop mammals, and they can move much faster than the wingless hosts. Therefore, birds have a potential of spreading ticks far beyond the home ranges of mammals and reptiles. Migrating bats can, like birds, cross barriers and move long distances in a short time, and could also have a potential of transporting ticks and tickborne pathogens, like Bartonella, Borrelia spp. and members of the family Rickettsiales (Gill et al., 2008; Mühldorfer, 2013).

\section{INTRODUCING NEW TICK SPECIES}

Although it has never been demonstrated that a new tick species, or a new tick pathogen, actually has been established in a new locality after being seeded there by birds, the evidence strongly suggests that this could happen. Hasle et al. (2009) studied northward migrating birds on four bird observatories situated north of 
the Skagerrak and Kattegat (Figure 1). From 9.768 passerine birds examined they found seven nymphs of Hyalomma rufipes. The Hyalomma species have a northern distribution limit in Southern Europe and North Africa (Estrada-Peña et al., 2004), and these nymphs would have had to be transported all the way from the Mediterranean to Norway, the last $130-150 \mathrm{~km}$ over open sea. Although many Hyalomma individuals may be brought to Norway every year, they would not settle in a cold temperate climate. Also, a larva of Dermacentor sp. was found on a willow warbler, Phylloscopus trochilus on Akerøya, Hvaler, an island off the Southern Norwegian coast. No Dermacentor sp. is endemic in Norway. These findings demonstrate that non-endemic tick species can be transported to new places, across geographic barriers. Considering an influx of 30-80 million passerines crossing the sea every spring, millions of ticks will be transported every year, and transport of exotic species would not be a rare event. The limiting factor will not be the ticks' dispersal ability, but the suitability of the area the ticks are released for the survival and reproduction of the ticks. A suitable climate is one of the prerequisites for establishing a tick species. For I. ricinus, which has its northern border of distribution in Norway and Sweden, the distribution correlates well with the isolines for the first frost night, number of days with snow cower, and the length of the growth season (Jaenson et al., 2009). As these isolines overlap we cannot from these data tell which climatic factor is the most important. As ticks are prone to desiccation (Daniel and Dusbábek, 1994), microclimatic conditions of sun, soil and vegetation cover will determine the individual ticks' chance of survival, much like in the Parable of the Sower (Mattew 13:5). Dermacentor reticulatus,

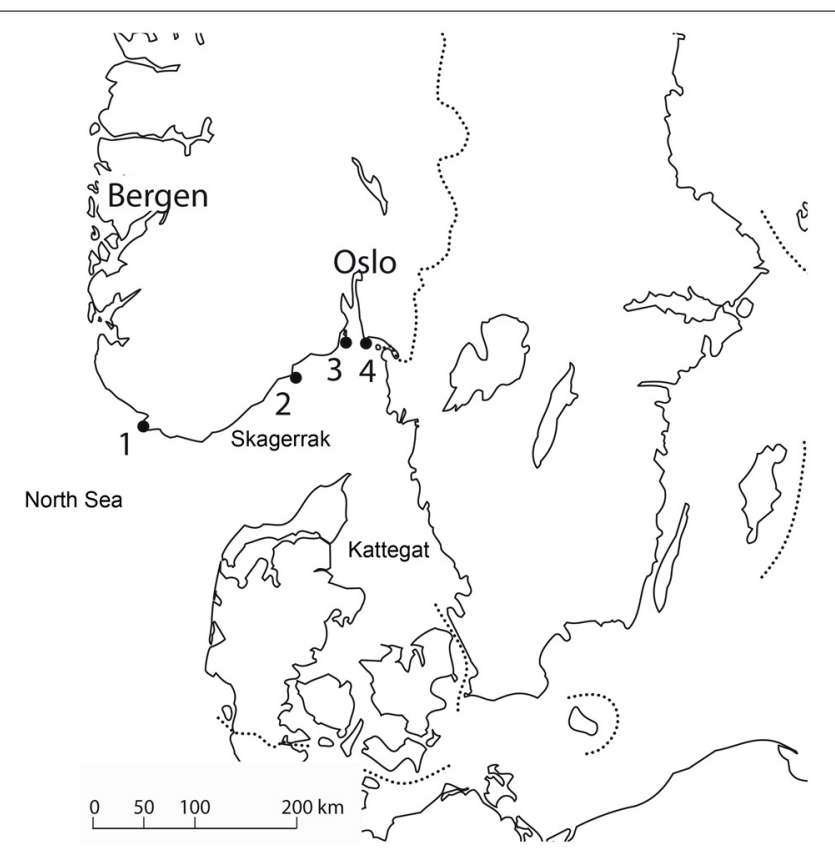

FIGURE 1 | Study area of Hasle et al. (2009). The participating bird observatories were: (1). Lista, (2). Jomfruland, (3). Store Færder, (4). Akerøya. Northward migrating birds would have to cross The North Sea, Skagerrak or Kattegat. which occurs in North Germany, is a vector for Babesia canis, F. tularensis, Rickettsia slovaka and C. Burnetii. It needs to complete the whole life cycle during one year (Dautel et al., 2006), which unlikely could take place during a normal year in Norway. However, future climate change could make Norway hospitable for this species. Conceivably, individual specimens of D. reticultus could transmit diseases after being transported to Norway by birds. An indirect evidence of this is a case of Babesia canis in a Norwegian dog that had not been abroad. D. reticulatus is the main vector for B. canis (Øines et al., 2010).

Apart from protection from frost and desiccation, a good tick habitat will depend on appropriate hosts. e.g., islands that harbor only small animals cannot support the full life cycle of I. ricinus, as the adults need hosts of a certain minimum size (Jaenson et al., 1994). Possibly, some tick species may be host specific, although this is controversial (Randolph, 2004).

For establishing a new population, an ecological niche must be available. According to the Competitive exclusion principle, two different species cannot sustainably occupy the same niche (Hardin, 1960). However, this is a theoretical consideration, and very similar species, like I. ricinus and I. persulcatus may have different climate requirements, e.g., I. persulcatus is much more cold-resistant than I. ricinus (Tokarevich et al., 2011). Therefore, their niches are not exactly identical. Furthermore, in a transient situation sympatric distribution can occur, as is shown in a recent publication showing a shift in the distribution range of I. persulcatus toward North and West in Karelen, Russia, into areas previously occupied by I. ricinus (Bugmyrin et al., 2013). It is shown for I. persulcatus (Filippova, 2002) as well as I. scapularis (Oliver et al., 1993 ) that they can readily mate and breed with $I$. ricinus, but the offspring is sterile. In a situation with coexistence, the reproductive success of the least abundant species would suffer much more than the most abundant species (Hasle, 2010). Ticks seeded in an area occupied by another species with which they can interbreed would have a very low chance of copulating with the same species.

Climate change, as well as changes in vegetation, is expected to influence the distribution of different tick species (EstradaPeña, 2001; Gray et al., 2009). Global warming would be expected to push a Northern limit of a distribution range further north. Such changes take place over decades, and dispersal by mammalian tick-hosts would be sufficient to keep up with the changes within a continent. However, if a geographical barrier, e.g., a sea, like Skagerrak and Kattegat, separates two hospitable areas, one with a tick species, and one without that species, and if the ecological niche is not occupied by another tick species, transport by birds would be a possible mechanism.

\section{TRANSPORT OF TICK-BORNE PATHOGENS}

Birds can potentially transport tick-borne pathogens by transport of infected ticks. In addition, the birds may act as amplifying host by being infected with tick-borne pathogens that can infect their parasitizing ticks, which can transmit the pathogens to subsequent hosts, or by hosting co-feeding ticks, i.e., ticks that feed near each other on the same host, when pathogens may pass from one tick to the other. 


\section{TRANSPORT OF INFECTED TICKS}

Transport of already infected ticks is an obvious mechanism of transporting tick-borne pathogens by birds, as most tick-borne pathogens survive transstadially, i.e., from larvae to nymphs, and from nymphs to adults. This is shown for Anaplasma marginale (Stich et al., 1989), Babesia divergens (Bonnet et al., 2007), Borrelia burgdorferi sensu lato (Bellet-Edimo et al., 2005) and TBEV, and is indeed a prerequisite for being a tick-borne pathogen (Randolph, 2011). However, the transstadial survival may not be $100 \%$, as some data indicate that B. afzelii can disappear from I. ricinus (Matuschka and Spielman, 1992) and B. burgdorferi s.s. from I. scapularis (Ogden et al., 2008) that are feeding on birds in Europe and North America respectively. Corresponding to this, Hasle et al. (2010) found that engorged ticks had a lower prevalence, i.e., odds ratio $0.24(P=0.004)$, of $B$. afzelii than unengorged ticks from birds. To spread a pathogen, a later stadium of the tick would have to parasitize a host that can mediate further transmission. Adult I. ricinus parasitize animals of the size of cats and larger (Jaenson et al., 1994), while small rodents and birds are the main reservoirs for the Borrelia spp. most common in Europe (Kurtenbach et al., 2002). Therefore, when fully engorged, Borrelia-infected nymphs molt to adult stage, it is not obvious that they can spread the pathogen further. However, although not very efficient, transovarial transmission is described for Babesia (Bonnet et al., 2007), Borrelia (BelletEdimo et al., 2005) and TBEV (Danielová and Holubová, 1991), which means that infected larvae can be transported by birds, and then molt to infected nymphs. Likewise, adult ticks may produce infected offspring after arrival on a new place, by transovarial transmission.

Human pathogens can also be transported by ticks that normally don't bite humans, as is shown for I. uriae (Olsen et al., 1995b).

In the case of TBEV, the virus is thought to be maintained in nature mainly by transmission through co-feeding on small rodents, as infected nymphs spread the virus to co-feeding larvae (Labuda and Randolph, 1999). It is almost exclusively nymphs and larvae of I. ricinus that can be transported by birds (Jaenson et al., 1994; Hasle et al., 2009). As the bird host would be the first host for the feeding larvae, they would not carry TBEV before entering the bird unless the virus is transmitted transovarially. Infected nymphs would proceed to adult stage after feeding, and would not feed on small rodents. Therefore, the TBEV-infected ticks transported by birds would be a dead-end for maintaining the TBEV in nature, without transovarial transmission. Assuming transovarial transmission, the TBEV could be seeded by birds to new areas if the climate, vegetation and hosts are suitable for the natural TBEV-cycle. In Norway, the first cases of TBE were notified in Southern Norway in 1998. Since then there has been an increase in annual cases, to the present $10-15$ cases per year. A very relevant question would be why this has not happened before. The answer may well be that it has happened before, but that the conditions necessary for maintaining the fragile cycle of TBEV (Randolph and Rogers, 2000) in the nature have not been present before. The distribution of TBEV in Scandinavia is discontinuous, with at least $300 \mathrm{~km}$ of land distance from the endemic areas in Sweden (Båhuslän) to the Agder counties in
Norway, while crossing the Skagerrak or Kattegat sea is a three to five hours flight for small passerine birds. It is difficult to find another explanation for this discontinuous distribution than transport via birds. This is the closest we can come to a proof that birds have seeded a tick-borne infection to a new area.

Babesia venatorum is an emerging tick-borne human disease in Europe. The first findings of this parasite in Norway have been on four nymphs of Ixodes ricinus brought to Norway by birds (Hasle et al., 2011). B. venatorum is a primarily a roe deer parasite (Duh et al., 2005), and adult I. ricinus readily feed on roe deer. Therefore, birds could effectively import and spread this parasite.

\section{BIRDS INFECTED BY TICK-BORNE PATHOGENS}

Birds can be infected by different genuses of Anaplasmataceae, i.e., Anaplasma phagocytophilum (de la Fuente et al., 2005), Rickettsia rickettsia (Lundgren et al., 1966) and Coxiella burneti (Babudieri and Moscovici, 1952). We have not found any experimental data confirming that birds infected by the Anaplasmataceae can transfer these pathogens to ticks. The Babesia spp. appears to be host specific, at least to the class, and some of them to one species (Peirce, 2000), no mammal Babesia sp. has been found infecting birds. Some species of Borrelia can infect birds, notably B. garinii, B. valaisiana, B. turdi (Gylfe et al., 2000; Richter et al., 2000) and B. burgdorferi s.s. (Anderson and Magnarelli, 1984; Anderson et al., 1986), but probably not B. afzelii (Kurtenbach et al., 2002), although this notion has been challenged by the findings of Franke et al. (2010). Hasle et al. (2010) found an odds ratio for Borrelia infection of 4.3 for ticks parasitizing the Turdus spp., i.e. 3.5 for B. garinii and 30.3 for B. valaisiana. This indicates that the Turdus spp. are more susceptible for infection with these Borrelia genospecies than other birds, and that the ticks got the pathogen during feeding on the bird. Thus, the Turdus spp., apart from being likely to carry ticks, were more likely to carry Borrelia-infected ticks than other bird genera. Therefore, the Turdus spp., especially the blackbird, may be important in the spreading and hosting of $B$. garinii, which is the main agent for neuroborreliosis (van Dam et al., 1993; Balmelli and Piffaretti, 1995).

The Borrelia species causing tick-borne relapsing fever are transmitted by soft ticks, Ornithodorus spp., which have a different biology from the I. ricinus-like ticks in that they live in nests and burrows and have a feeding time of just a few minutes Johnson and Golighty (2000). These ticks would not be prone to long-range transport by birds, but the birds may contract the Borrelia, which can be transmitted further, as suggested for Borrelia hermsii, by (Schwan et al., 2007).

Transport of tick-borne pathogens from one endemic area to another could have an impact, even if the pathogens already occur there, by spreading new strains to new areas.

\section{TRANSFER OF PATHOGENS THROUGH CO-FEEDING}

Transmission of a tick-borne pathogen through co-feeding has been demonstrated for the tick-borne encephalitis-virus (TBEV) on Myodes glareolus and Apodemus sylvaticus (Labuda and Randolph, 1999), but no data exists for such transmission of TBEV on birds. In Waldenström et al's material (2007) they found 
three TBEV-positive $I$. ricinius, one nymph and two larvae, on one individual European robin, Erithacus rubecula, which strongly suggests that the bird either was viremic or that transmission through co-feeding did occur.

Also, for Borrelia this mechanism has been suggested for mammals. Gern and Rais (1996) demonstrated transmission of B. burgdorferi between co-feeding I. ricinus on $\mathrm{AKR} / \mathrm{N}$ mice in the laboratory. By using a generalized linear model (GLM) Hasle et al. (2010) found that ticks that were co-feeding on birds with ticks infected with one genospecies of Borrelia had an increased probability of being infected with the same genospecies. A tick co-feeding with another tick with $B$. afzelii had an odds ratio of 3.9. If the statement that birds cannot be infected with B. afzelii is correct, this is an indication that non-systemic transmission between co-feeding ticks has occurred. For B. valaisiana the odds ratio for ticks co-feeding with other ticks with $B$. valaisiana was 760 , compared to the average prevalence. The latter could partly be explained by the effect of feeding on the Turdus spp., and by systemic infection of the bird. Geller et al. (2013) found the same strain of B. afzelii (PGau) on two I. ricinus nymphs that were feeding on the same Great tit (Parus major), a finding that suggests transmission through co-feeding.

The existing data support the hypothesis that all the three mechanisms of spreading tick-borne pathogens by birds may occur in the nature.

\section{MIGRATION ROUTES}

Knowledge of the bird migration routes is crucial for understanding the possible impact of birds as spreaders of ticks and tick-borne pathogens. For instance, the main direction of migration in Europe is NE/SW for the Turdus spp., E. rubecula, Phoenicurus phoenicurus, Prunella modularis and Troglodytes troglodytes (Gjershaug et al., 1994; Bruderer, 1997; Fransson and Hall-Karlsson, 2008), which are all species with a high prevalence of tick infestation (Hasle et al., 2009; Marsot et al., 2012). These

\section{REFERENCES}

Alekseev, A. N., Dubinna, H. V., Semenov, A. V., Cazimir, V., and Bolshakov, C. V. (2001). Evidence of ehrlichiosis agents found in ticks (Acari: Ixodidae) collected from migratory birds. J. Med. Entomol. 38, 471-474. doi: 10.1603/00222585-38.4.471

Anderson, J. F., Johnson, R. C., Magnarelli, L. A., and Hyde, F. W. (1986). Involvement of birds in the epidemiology of the Lyme disease agent Borrelia burgdorferi. Infect. Immun. 51, 394-396.

Anderson, J. F., and Magnarelli, L. A. (1984). Avian and mammalian hosts for spirochete-infected ticks and insects in a Lyme disease focus in Connecticut. Yale J. Biol. Med. 57, 627-641.

Babudieri, B., and C. Moscovici. (1952). Experimental and natural infection of birds by Coxiella burneti. Nature 169, 195-196. doi: 10.1038/169195a0

Balmelli, T., and Piffaretti, J.-C. (1995). Association between different clinical manifestations of Lyme disease and different species of Borrelia burgdorferi sensu lato. Res. Microbiol. 146, 329-340. doi: 10.1016/0923-2508 (96)81056-4

Bellet-Edimo, R., Betschart, B., and Gern, L. (2005). Frequency and efficiency of transovarial and subsequent transstadial transmission of Borrelia burgdorferi sensu lato in Ixodes ricinus ticks. Bull. de la Société Neuchâteloise des Sciences Naturelles 128, 117-125.

Bjöersdorff, A., Bergström, S., Massung, R. F., Haemig, P. D., and Olsen, B. (2001). Ehrlichiainfected ticks on migrating birds. Emerg. Infect. Dis. 7, 877-879.

Bonnet, S., Jouglin, M., Malandrin, L., Becker, C., Agoulon, A., l'Hostis,

species would be unlikely to transport the TBEV from Central to North-West Europe, but could possibly transport this virus from Central to South-West Europe. On the other hand, species that migrate along a more N/S direction across the Alps, like Sylvia curruca, S. communis and S. atricapilla, or NW/SE, like Motacilla alba and Luscinia svecica (Gjershaug et al., 1994; Fransson and Hall-Karlsson, 2008) could potentially cross the Skagerrak sea and transport ticks carrying TBEV from the TBE-endemic areas in Central Europe to Norway and Sweden. During NW migration Motacilla alba and Luscinia svecica may pass areas endemic for Ixodes persulcatus before reaching Sweden, and could, theoretically, introduce this tick species to Sweden, as the climate in Sweden would be suitable for I. persulcatus. However, the ecological niche is already occupied, by I. ricinus, and I. persulcatus would therefore be unlikely to colonize Sweden, even if they were brought there by birds. On the other hand, to bring this speculation further, if they can be transported past areas occupied by $I$. ricinus it could still remain a possibility for colonization of I. persulcatus in Sweden. I. persulcatus survives extreme winter temperatures in Siberia, and could possibly do that in Scandinavia as well. The findings of $I$. persulcatus and human cases with $\mathrm{S}-\mathrm{TBEV}$ in Kokkola $\left(\mathrm{N} 63^{\circ} 50^{\prime} \mathrm{E} 23^{\circ} 07^{\prime}\right)$, Finland, several hundred kilometres from the known western distribution range of I. persulcatus (Jääskeläinen et al., 2006), suggests long distance transport by birds.

\section{CONCLUSIONS}

Transport of ticks by migratory birds, including tick species and tick-borne pathogens that are not endemic to a new area, is a common event. Establishment of a new tick species in an area will require favorable climate, vegetation and hosts, and an available ecological niche. New tick-borne pathogens could be spread if there are susceptible tick and vertebrates hosts present. It still remains to prove if this way of dispersal has happened.

M., et al. (2007). Transstadial and transovarial persistence of Babesia divergens DNA in Ixodes ricinus ticks fed on infected blood in a new skin-feeding technique. Parasitology 134, 197-207. doi: 10.1017/S0031182006001545

Bruderer, B. (1997). The study of bird migration by radar. Part 2: major achievements. Naturwissenschaften Aufsätze 84, 45-54. doi: 10.1007/s001140050348

Bugmyrin, S. V., Bespyatova, L. A., Korotkov, Y. S., Burenkova, L. A., Belova, O. A., Romanova, L. I. U., et al. (2013). Distribution of Ixodes ricinus and I. persulcatus ticks in southern Karelia (Russia). Ticks Tick Borne Dis. 4, 57-62. doi: 10.1016/j.ttbdis. 2012.07.004

Comstedt, P., Bergström, S., Olsen, B., Garpmo, U., Marjaavara, L., Mejlon, H., et al. (2006). Migratory passerine birds as reservors of
Lyme borreliosis in Europe. Emerg. Infect. Dis. 12, 1087-1095. doi: 10.3201/eid1207.060127

Daniel, M., and Dusbábek, F. (1994). "Micrometeorological and microhabitat factors affecting maintenance and dissemination of tickborne diseases in the environment," in Ecological Dynamics of Tick-Borne Zoonoses, eds D. E. Sonenshine and T. N. Mather (New York, NY, Oxford: Oxford University Press), 91-138.

Daniels, T. J., Battaly, G., Liveris, D., Falco, R. C., and Schwarz, I. (2002). Avian reservoirs of the agent of Human Granulocytic Ehrlichiosis? Emerg. Inf. Dis. 8, 1524-1525. doi: 10.3201/eid0812.010527

Danielová, V., and Holubová, J. (1991). "Transovarial transmission rate of tick-borne encephalitis virus in Ixodes ricinus ticks," in Modern Acarology, eds F. Dusbabek and V. Bukva (The 
Hague: Academia, Prague and SPB Academic Publishing), 7-10.

Dautel, H., Dippel, C., Oehme, R., Hartelt, K., and Schettler, E. (2006). Evidence for an increased geographical distribution of Dermacentor reticulatus in Germany and detection of Rickettsia sp. RpA4. Int. J. Med. Microbiol. 296(Suppl. 40), 149-156. doi: 10.1016/j.ijmm.2006. 01.013

de la Fuente, J., Naranjo, V., RuizFons, F., Höfle, U., Fernandéz de Mera, I. G., Vilanúa, D., et al. (2005). Potential vertebrate reservoir hosts and invertebrate vectors of Anaplasma marginale and A. Phagocytphilum in central spain. Vector Borne Zoonotic Dis. 5, 390-401. doi: 10.1089/vbz.2005. 5.390

Duh, D., Petrovec, M., Bidovec, A., and Avsic-Zupanc, T. (2005). Cervids as Babesiae hosts, Slovenia. Emerg. Infect. Dis. 11, 1121-1123.

Elfving, K., Olsen, B., Bergström, S., Waldenström, J., Lundkvist, Å., Sjöstedt, A., et al. (2010). Dissemination of spotted fever Rickettsia agents in Europe by migrating birds. PLoS ONE 5:e8572. doi: 10.1371/journal. pone. 0008572

Estrada-Peña, A. (2001). Forecasting habitat suitability for ticks and prevention of tick-borne diseases. Vet. Parasitol. 98, 111-132.

Estrada-Peña, A., Bouattour, A., Camicas, J.-L., and Walker, A. R. (2004). Ticks of the Domestic Animals in the Mediterranean Reigion. A Guide to Identification of Species. Zaragoza: University of Zaragoza.

Filippova, N. A. (2002). Forms of sympatry and possible ways of microevolution of closely related species of the group Ixodes ricinuspersulcatus (Ixodidae). Acta Zool. Lituan. 12, 215-227. doi: 10.1080/ 13921657.2002.10512509

Franke, J., Hildebrandt, A., and Dorn, W. (2012). Exploring gaps in our knowledge on Lyme borreliosis spirochaetes - updates on complex heterogeneity, ecology, and pathogenicity. Ticks Tick Borne Dis. 4, 11-25. doi: 10.1016/j.ttbdis.2012. 06.007

Franke, J., Moldenhauer, A., Hildebrandt, A., and Dorn, W. (2010). Are birds reservoir hosts for Borrelia afzelii? Ticks Tick Borne Dis. 1, 109-112.

Fransson, T., and Hall-Karlsson, S. (2008). Swedish Bird Ringing Atlas, Vol. 3. Stockholm: Naturhistoriska riksmuseet \& Sveriges Ornitologiska Förening.
Geller, J., Nazarova, L., Katargina, O., Leivits, A., Järvekülg, L., and Golovljova, I. (2013). Tick-borne pathogens in ticks feeding on migratory passerines in western part of Estonia. Vector Borne Zoonotic Dis. 13, 443-448. doi: 10.1089/vbz.2012. 1054

Gern, L., and Rais, O. (1996). Efficient transmission of Borrelia burgdorferi between cofeeding Ixodes ricinus ticks (Acari: Ixodidae). J. Med. Entomol. 33, 189-192.

Gill, J. S., Ullmann, A. J., Loftis, A. D., Schwan, T. G., Raffel, S. J., and Schrumpf, M. E. (2008). Novel relapsing fever spirochete in bat tick [letter]. Emerg. Infect. Dis. 14, 522-523. doi: 10.3201/eid1403. 070766

Gjershaug, J. O., Thingstad, P. G., Eldøy, S., and Byrkjeland, S (eds.). (1994). Norsk Fugleatlas. ("Norwegian bird atlas") [in Norwegian]. Klæbu: Norsk Ornitologisk Forening.

Gray, J. S., Dautel, H., Estrada-Peña, A., Kahl, O., and Lindgren, E. (2009). Review article. Effects of climate change on ticks and tick-borne diseases in Europe. Interdiscip. Perspect. Infect. Dis. 2009:593232. doi: 10.1155/2009/593232

Gylfe, A., Bergström, S., Lundström. J., and Olsen, B. (2000). Reactivation of Borrelia infection in birds. Nature 403, 724-725. doi: $10.1038 / 35001663$

Hanincova, K., Schafer, S. M., Etti, S., Sewell, H. S., Taragelová, V. Ziak, D., et al. (2003). Association of Borrelia afzelii with rodents in Europe. Parasitology 126, 11-20. doi: 10.1017/S0031182002002548

Hardin, G. (1960). The competitive exclusion principle. Science 131, 1292-1297.

Hasle, G. (2010). Dispersal of Ticks and Tick-Borne Pathogens by Birds. Dynamics of Birds' Transport of Ticks to Norway. Ph.D. thesis. Department of Biology, University of Oslo and Institute for Health and Society, Faculty of Medicine, University of Oslo. Available online at: (https://www.duo.uio.no/bitstream/handle/123456789/27960/dr avhandling-hasle.pdf?sequence $=3$ )

Hasle, G., Bjune, G. A., Edvardsen, E., Jakobsen, C., Linnehol, B. A., Røer, J. E., et al. (2009). Transport of ticks by migratory passerine birds to Norway. J. Parasitol. 95, 1342-1351.

Hasle, G., Bjune, G. A., Midthjell, L., Røed, K. H., and Leinaas, H. P. (2010). Transport of Ixodes ricinus infected with Borrelia species to Norway by northward-migrating passerine birds. Ticks Tick Borne Dis 2, 37-43.

Hasle, G., Leinaas, H. P., Røed, K. H., and Øines, Ø. (2011). Transport of Babesia venatorum-infected Ixodes ricinus to Norway by northward migrating passerine birds. Acta Vet. Scand. 53, 41 .

Hoogstraal, H., Kaiser, M. N., Traylor, M. A., Gaber, S., and Guindy, E. (1961). Ticks (Ixodidea) on birds migrating from Africa to Europe and Asia. Bull. World Health Organ. 24, 197-212.

Hoogstraal, H., Kaiser, M. N., Traylor, M. A., Gaber, S., Guindy, E., and Gaber, S. (1963). Ticks (Ixodidae) on birds migrating from Europe and Asia to Africa. Bull. World Health Organ. 28, 235-262.

Ishiguro, F., Takada, N., Masuzawa, T. and Fukui, T. (2000). Prevalence of Lyme disease Borrelia spp. in ticks from migratory birds on the Japanese mainland. Appl. Environ. Microbiol. 66, 982-986.

Jääskeläinen, A. E., Tikkakoski, T. Uzcátegui, N. Y., Alekseev, A. N., Vaheri, A., and Vapalahti, O. (2006). Siberian subtype tickborne encephalitis virus, Finland. Emerg. Infect. Dis. 12, 1569-1571. doi: 10.3201/eid1210.060320

Jaenson, T. G. T., Eisen, L., Comstedt, P., Mejlon, H. A., Lindgren, E., Bergstöm, S., et al. (2009). Risk indicators for the tick Ixodes ricinus and Borrelia burgdorferi sensu lato in Sweden. Med. Vet. Entomol. 23, 226-237. doi: 10.1111/j.1365 2915.2009.00813.x

Jaenson, T. G. T., Tälleklint, L. Lundqvist, L., Olsén, B., Chirico, J., and Mejlon, H. (1994) Geographical distribution, host associations, and vector roles of ticks (Acari: Ixodidae, Argasidae) in Sweden. J. Med. Entomol. 31, 240-256.

Johnson, W. D., and Golighty, L. M. (2000). "Borrelia Species (Relapsing fever)," in Principles and Practice of Infectious Diseases, 5th Edn., eds G. L. Mandell, R. G. Douglas, and J. T. Bennett (Philadelphia; London; Toronto; Montreal; Sydney; Tokyo Edinburgh: Churchill Livingstone), 2502-2504

Kjelland, V., Stuen, S., Skarpaas, T., and Slettan, A. (2010). Borrelia burgdorferi sensu lato in Ixodes ricinus ticks collected from migratory birds in Southern Norway. Acta Vet. Scand. 6, 52-59.

Kurtenbach, K., de Michelis, S., Etti, S., Schäfer, S. M., Sewell, H.-S., Brade, V., et al. (2002). Host association of Borrelia burgdorferi sensu lato - the key role of host complement. Trends Microbiol. 10, 74-79. doi: 10.1016/S0966-842X(01)02298-3

Labuda, M., and Randolph, S. E. (1999). Survival of tickborne encephalitis virus: cellular basis and environmental determinants. Zentralbl. Bakteriol. 289, 513-524. doi: 10.1016/S0934-8840(99)80005-X

Lundgren, D. L., Thorpe, B. D., and Haskell, C. D. (1966). Infectious diseases in wild animals in utah VI. Experimental infection of birds with rickettsia rickettsii. J. Bacteriol. 91, 963-966.

Marsot, M., Henry, P.-Y., Vourc'h, G., Gasqui, P., Ferquel, E., Laignel, L., et al. (2012). Which forest bird species are the main hosts of the tick, Ixodes ricinus, the vector of Borrelia burgdorferi sensu lato, during the breeding season? Int. J. Parasitol. 42, 781-788.

Matuschka, F.-R., and Spielman, A. (1992). Loss of Lyme disease spirochetes from Ixodes ricinus ticks feeding on European blackbirds. Exp. Parasitol. 74, 151-115. doi: 10.1016/0014-4894(92) 90042-9

Mehl, R., Michaelsen, J., and Lid, G. (1984). Ticks (Acari, Ixodides) on migratory birds in Norway. Fauna norv. B 31, 46-58.

Mühldorfer, K. (2013). Bats and bacterial pathogens: a review. Zoonoses Public Health 60, 93-103. doi: 10.1111/j.1863-2378.2012.01536.x

Nicholls, T. H., and Callister, S. M. (1996). Lyme disease spirochetes in ticks collected from birds in Midwestern United States. J. Med. Entomol. 33, 379-338.

Nuorteva, P., and Hoogstraal., H. (1963). The incidence of ticks (Ixodoidea,Ixodidae) on migratory birds arriving in Finland during the spring of 1962. Ann. Med. Exp. Biol. Fenn. 41, 457-468.

Ogden, N. H., Lindsay, L. R. Hanincová, K., Barker, I. K., Bigras-Poulin, M., Charron, D. F., et al. (2008). Role of migratory birds in introduction and range expansion of Ixodes scapularis ticks and of Borrelia burgdorferi and Anaplasma phagocytophilum in Canada. Appl. Environ. Microbiol. $74,1780-1790$.

Øines, Ø., Storli, K., and Brun-Hansen, H. (2010). First case of babesiosis caused by Babesia canis in a dog from Norway. Vet. Parasitol. 171, 350-353.

Oliver, J. H., Owsley, M. R., Hutcheson, H. J., James, A. M., Chen, C., Irby, W. S., et al. (1993). Conspecificity of the ticks Ixodes 
scapularis and I. dammini (Acari: Ixodidae). J. Med. Entomol. 30, 54-63.

Olsen, B., Jaenson, T. G. T., and Bergström, S. (1995a). Prevalence of Borrelia burgdorferi sensu lato-infected ticks on migrating birds. Appl. Environ. Microbiol. 61, 3082-3087.

Olsen, B., Duffy, D. C., Jaenson, T. G. T., Gylfe, A., Bonnedahl, J., and Bergstrom, S. (1995b). Transhemispheric exchange of lyme disease pirochetes by seabirds. J. Clin. Microbiol. 33, 3270-3274.

Peirce, M. A. (2000). A taxonomic review of avian piroplasms of the genus Babesia Starcovici, 1893 (Apicomplexa: Piroplasmorida: Babesiidae). J. Nat. Hist. 34, 317-332. doi: 10.1080/002229300299507

Poupon, M.-A., Lommano, E., Humair, P.-F., Douet, V., Rais, O., Schaad, M., et al. (2006). Prevalence of Borrelia burgdorferi sensu lato in ticks collected from migratory birds in Switzerland. Appl. Environ. Microbiol. 72, 976-979. doi: 10.1128/AEM.72.1.976-979. 2006

Randolph, S. E. (2004). Tick ecology: processes and patterns behind the epidemiological risk posed by ixodid ticks as vectors. Parasitology 129, S37-S65. doi: $10.1017 / S 0031182004004925$

Randolph, S. E. (2011). Transmission of tick-borne pathogens between co-feeding ticks: milan Labuda's enduring paradigm. Ticks Tick Borne Dis. 2, 179-182. Available online at: (http://www.sciencedirect. com/science/article/pii/S1877959X1 1000586)

Randolph, S. E., and Rogers, D. J. (2000). Fragile transmission cycles of tick-borne encephalitis virus may be disrupted by predicted climate change. Proc. Biol. Sci. 267, 1741-1744. doi: 10.1098/rspb. 2000.1204

Richter, D., Spielman, A., Komar, N., and Matuschka, F.-R. (2000). Competence of American robins as reservoir hosts for Lyme disease spirochetes. Emerg. Infect. Dis. 6, 133-138. doi: 10.3201/eid0602.000205

Scharf, W. C. (2004). Immature ticks on birds: temporal abundance and reinfestation. Northeast. $\quad$ Nat. 11, 143-150. doi: 10.1656/1092-6194(2004)011 [0143:ITOBTA]2.0.CO;2

Schwan, T. G., Raffel, S. J., Schrumpf, M. E., and Porcella, S. F (2007). Diversity and distribution of Borrelia hermsii. Emerg. Infect. Dis. 13, 436-442. doi: 10.3201/eid1303.060958

Smith, R. P., Rand, P. W., Lacombe, E. H., Morris, S. R., Holmes, D. W., Caporale, D. A. (1996). Role of bird migration in the long-distance dispersal of Ixodes dammini, the vector of Lyme disease. J. Infect. Dis. 174, 221-224.

Socolovschi, C, Reynaud, P., Kernif, T., Didier Raoult, D., and Parola,
P. (2012). Rickettsiae of spotted fever group, Borrelia valaisiana, and Coxiella burnetii in ticks on passerine birds and mammals from the Camargue in the south of France. Ticks Tick Borne Dis. 3, 355-360.

Stafford, K. C., Bladen, V. C., and Magnarelli, L. A. (1995). Ticks (Acari: Ixodidae) infesting wild birds (aves) and white-footed mice in lyme, CT. J. Med. Entomol. 32, 453-466.

Stich, R. W., Kocan, K. M., Palmer, G. H., Ewing, S. A., Hair, J. A., and Barron, S. J. (1989). Transstadial and attempted transovarial transmission of Anaplasma marginale by Dermacentor variabilis. Am. J. Vet. Res. 50, 1377-1380.

Tokarevich, N. K., Tronin, A. A., Blinova, O. V., Buzinov, R. V., Boltenkov, V. P., Yurasova, E. D., et al. (2011). The impact of climate change on the expansion of Ixodes persulcatus habitat and the incidence of tick-borne encephalitis in the north of European Russia. Glob. Health Action 4,8448 .

van Dam, A. P., Kuiper, H., Vos, K., Widjojokusumo, A., de Jongh, B. M., Spanjaard, L., et al. (1993). Different genospecies of Borrelia burgdorferi are associated with distinct clinical manifestations of Lyme borreliosis. Clin. Infect. Dis. 17, 708-717. doi: 10.1093/clinids/17.4.708

Waldenström, J., Lundkvist, A., Falk, K. I., Garpmo, U., Bergström,
S., Lindegren, G., et al. (2007). Migrating birds and Tickborne encephalitis virus. Emerg Infect. Dis. 13, 1215-1218. doi: 10.3201/eid1308.061416

Weisbrod, A. R., and Johnson, R. C. (1989). Lyme disease and migrating birds in the Saint Croix Rive Valley. Appl. Environ. Microbiol. 55, 1921-1924.

Conflict of Interest Statement: The author declares that the research was conducted in the absence of any commercial or financial relationships that could be construed as a potential conflict of interest.

Received: 30 April 2013; accepted: 15 August 2013; published online: 10 September 2013.

Citation: Hasle G (2013) Transport of ixodid ticks and tick-borne pathogens by migratory birds. Front. Cell. Infect. Microbiol. 3:48. doi: 10.3389/fcimb. 2013.00048

This article was submitted to the journal Frontiers in Cellular and Infection Microbiology

Copyright () 2013 Hasle. This is an open-access article distributed under the terms of the Creative Commons Attribution License (CC BY). The use, distribution or reproduction in other forums is permitted, provided the original author(s) or licensor are credited and that the original publication in this journal is cited, in accordance with accepted academic practice. No use, distribution or reproduction is permitted which does not comply with these terms. 